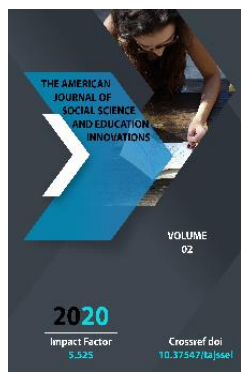

\title{
Some Aspects Of Contemporary Saudi Literature Development
}

\author{
Nargiza Saidova
}

Tashkent State University Of Oriental Studies, Uzbekistan

Copyright: Original content from this work may be used under the terms of the creative commons attributes 4.0 licence.

\section{ABSTRACT}

This article is devoted to some aspects of the development of modern Saudi literature. The article describes the first attempt to create a prose genre, the development of the short story genre, and the changes that have occurred in modern Saudi literature in recent years.

\section{KEYWORDS}

Short story genre, critical research, literary criticism, writers ' Union, Saudi prose, literary trends.

\section{INTRODUCTION}

The formation of ancient and medieval literature on the territory of the modern state of Saudi Arabia took place in line with the development of general Arab culture.

In the fifth - seventh $A D$, Bedouin poetry was well developed in the Arabian Peninsula (1-20). In the first half of the seventh century, the Qur'an had been created, which has survived to the present day, the text of which was compiled under the third Rightly Guided Caliph Uthman (644-656). The scientific study of the Qur'an began in the second half of the nineteenth century (2-105).

To this day, Bedouin poetry and the Qur'an are recognized as classics of early Arabic literature in all Arab countries. 
After the establishment of the Caliphate and the relocation of the centers of literary life to Damascus, Baghdad, and Cairo, the development of Saudi literature stopped in development for a long time, and it was mainly represented by folk poetry.

\section{MATERIALS AND METHODS}

Due to a number of objective circumstances, Arabia has been cut off from the outside world for centuries and deprived of the possibility to communicate across world culture. At the beginning of the twentieth century, the Arabian Peninsula still retained the socio economic structure that developed in the middle ages, and spiritual life was determined mainly by tribal relations. The writers' outlook on life remained narrow, and their social views were limited.

In artistic terms, like their predecessors from ancient times, they followed national traditions, which were slightly "reworked", adapting them to the needs of their time.

This preservation of traditions for many years predetermined the stability of the canons and the fate of Arabian literature as a self-sufficient and underdeveloped phenomenon.

The new things that began to emerge in the 1920 , during the first signs of capitalist relations, for a long time could not be reflected in literature at the language, genre and species levels precisely because of its archaic nature. Poetry remained the only type of literary literature.

Various changes in the sphere of public life dictated the need for new forms in the field of artistic creativity. And, therefore, since the 1930s, under the influence of the literature of neighboring Arab countries, Saudi Arabia has put forward a number of poets, journalists, and writers, and its literature began to combine educational, romantic, and realistic trends.

The contemporary prose of Saudi Arabia is still in its infancy. In prose works, as in poetry, the impact of the literatures of Egypt and Syria remains strong, and especially the impact of the Syro - American group. Translations of samples of world literature do not pass without a trace. Many poets write prose at the same time, so the trends and movements inherent in Saudi poetry are mostly typical of its prose. Early examples of prose in Hejaz still stand on the edge of prose and poetry. Many of them are characterized by an emotional oversaturation of content, especially such features as romantic elation, lyrical exhilaration, abundance of imagination, and rhetoric. Those are the short stories of Abu Karl, Aziz Diya from Hejaz (3).

New forms of reflection on life in Saudi literature, such as short stories and journalistic essays, which appeared from time to time in the pages of the newspapers Al - Yamama and Saut al - Hejaz began to take shape with the advent of the periodical press in Hejaz (4-5).

The first attempt to create, a work of prose genre in modern Saudi literature was made in 1930, when Abdul-Quddus al-Ansari's novella The twins, which belongs to the genre of didactic short story, had been published.

The main theme of the novella, whose heroes are the twin brothers Rashid and Farid, is a comparative analysis of the national and foreign education systems. As the author wrote himself in the preface, he wanted to show the harm caused to the Arab world by foreign schools that instill dubious and obscene rules of behavior in Eastern youth. 
Compositionally and artistically, this first experience was far from perfect.

In the events of the work, an attempt is made to describe the reality of education and the ideological direction in each of these schools, and their influence on the fate of the characters.

The author's goal is to warn the nation about the dangers of foreign education, and he wants "the reader to find in the novella a real picture of the harm of foreign educational institutions in the East, which instill dubious and obscene rules of behavior in Eastern youth" (5-5).

Rashid, who studied at the national school, achieved great success in life, he was given the title "Pasha" by Royal decree, and Farid, who studied at a foreign school, tragically died in one of places of entertainment in Paris.

Later, the theme raised in The Twins was continued in another short story by al-Ansari The Balm of Oblivion. Al - Ansari, a prominent scholar, has published many books on the history and material culture of Saudi cities, monuments of Arabic classical literature, and the reform of the written language. For fifty years, he has published a solid literary magazine Al - Manhal.

The realistic trend in Saudi prose after world war II (1939-1945) is represented by the short stories by Amin Salem Rumeyh (collection of short stories And Ears Love); Abdallah Munaa ( collection Search); Yusuf bin al-Sheikh Yaqub ( short story The Thief ) and others; the novels by Hassan Nasif (The Notes of a Former Student) and Abd al-Salam Hashim Hafiz (The Imprisoned Girl, Talking Hearts). And, although the short stories of realist writers still have strong elements of sentimentalism, and they are characterized by excessive emotionality and elation of style, their works are in defense of national interests, respond to the social struggle of various representatives of society.

Gradually, under the direct influence of the literary trends of Egypt and Syria, the prose writers of Arabia increasingly turn their eyes to the problems of social life, highlight the mores, scourge the inertia of some young people, educate them on high ideals, talk about the fate and role of women in Arabian society, and touch on religious topics. The style of such works corresponds to the norms of prose, accuracy and clarity of expression come to the fore, logic of construction, sensory perceptions and emotions give way to reason in these short stories.

\section{RESULTS AND DISCUSSIONS}

In 1957, Abd al-Salam Hashim Hafiz published the first novel Samra of Hejaz dedicated to the protection of women's rights.

In the same year, Hamid Damanhuri published the first major work The Price of Sacrifice dealing with issues of everyday life and traditions in the family.

Journalism and literary criticism of the $1950 \mathrm{~s}$ are represented by the works of Muhammad Hassan Awwad ("Frank thoughts", "Inspired by folk life", "Reflections on literature and life"); Ahmed Abd al-Ghafur Attar ("A drop from a reed pen"); Abdullah bin Khalis, Saad alBawaridi; progressive literary critic Abdullah Abd al-Jabbar ("Trends in modern literature in the Central part of the Arabian Peninsula").

In the 1970s, the works of Saudi women writers appeared for the first time in the literary arena. Samira bint al - Jazeera ( means Samira is daughter of the Peninsula - alias of Samira Muhammad Khashagji) has published 
several collections of short stories with sentimental, sad titles: "The radiance of your eyes", "Sobbing memories", "I said goodbye to hope", "Valley of tears", etc.

Another writer Hind Saleh Bagaffar wrote her first short story Lost innocence.

However, the short stories of these writers were far from the problems of Saudi society, since the events in them took place outside of Saudi Arabia and the characters had nothing to do with the Saudi environment.

The short story Tomorrow will be Thursday by another Saudi woman writer, Khudi ar Risheda, also does not belong to the Saudi environment, but it is more perfect in artistic terms than the works of previous writers.

One of the most famous literary study scholars of Saudi literature is Al - Ansari, who has published many books on the history and material culture of Saudi cities, monuments of Arabic classical literature, and issues of written language reform.For fifty years, he has published a solid literary magazine, al Manhal.

In December 2011, the International literary forum organized by the Union of writers and writers of the United Arab Emirates ended its work in Sharjah (6).

The key issues of the forum were the development of the short story genre and literary criticism in the Gulf States.

Much interest was aroused at the forum by the critical study "The development of the short story genre in the Kingdom of Saudi Arabia", written by Abdallah Khalef, the literary critic from Bahrain (7-4).
In his research, Abdallah Khalifa notes that in the initial period of its development, the genre of short stories in the Kingdom of Saudi Arabia pursued didactic goals, and it was entirely aimed at implementing the ideas of Enlightenment. A literary critic from Bahrain considers that the lack of the human factor as the most important lever of socio - political development of society and the exaggerated attention to human individuality is considered to be a significant drawback of these short stories. According to Khalifa, such development of the short story aheads of changes that must occur in the minds of people adequately to the relevant stages of the society development in order to perceive progressive ideas of the Enlightenment.

Khalifa believes that a great contribution to the development of the short story genre was made by the generation of writers represented by Muhammad Ulwan (the collection "Bread and silence"); Hussein Ali Hussein (the short story "Tthe visitor to Medina"); Abdallah alSalami (the collection "Without a goal for the herd"). A literary critic from Bahrain sees in these works the undoubted impact of Romanticism on the works of many famous Egyptian writers, and especially Ihsan Abd alQuddus. However, according to Khalifa, romantic works do not reflect social conflicts or political, psychological and other changes taking place in society, but express a desire to avoid depicting the surrounding reality.

In his research, Khalifa examines the works of Fahd al-Attiq whose short stories are characterized by tension and transparency, but the harmony of which brings them closer to lyrical works.

Khalifa reviews the work of Ibrahim Muhammad al-Naml who writes realistic stories filled with the author's philosophical reflections on life, death and being. 
Khalifa also mentions the names of Abd al-Aziz Mashri, Muhammad Mansur al-Shaq, as well as the names of such writers as Sharifa alShamlan, Amina bint Mansur al-Badri and others, and he makes a conclusion on the lack of event in many works of the short story genre.

Khalifa also notes the large number of works in Saudi literature in recent years that belong to the novel genre which indicates its rapid development.

In conclusion of his research, noting the progressive development of modern literature in Saudi Arabia, Khalifa draws attention to the mixing and interpenetration of various genres that makes it difficult to distinguish between them.

The critic also notes that in recent years, qasida has stopped following traditional canons, and has acquired some features that bring it closer to a prose work.

As for the generation of young writers from the Arab States of the Persian Gulf whom Khalifa called "the generation of the Internet", as the literary critic notes, their entry into the world literary process and possession of the latest artistic methods, significantly outstrips the natural course of society development.

\section{CONCLUSION}

Currently, in Saudi Arabia, the state pays great attention to cultural issues and the development of literature. The General Governing Council for Youth Affairs under the Ministry of Culture supports and encourages young artistic talents by providing them with cultural clubs, youth hostels and more than seventy youth centers. In addition, the Council is responsible for providing financial assistance to literary clubs and publications of the Saudi Arabian society for culture and the arts, publishing books and twice a month cultural magazines as well as supervising the award of the State prize for literature which is awarded annually to three of the most outstanding Saudi writers.

\section{REFERENCES}

1. M. Filshtinsky. Arabic literature in the middle ages. - M. 1977. p. 20

2. M. Filshtinsky. Arabic literature in the middle ages. - M. 1977. p. 105

3. Hijaz is the name of a province in Saudi Arabia

4. al - Ansari "Gemini" ("at - Taw'aman"). Preface 1944. 3-edition. p. 5

5. al - Ansari "The Twins" ("at - Taw'aman"). Preface 1944. 3-edition. p. 5

6. sharja is one of the seven Emirates that make up the state of the United Arab Emirates.

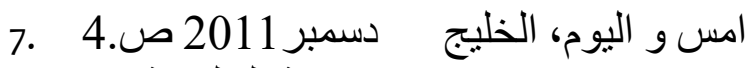
صesterday and today of the genre of the story in the states of the Persian Gulf. The newspaper "al-Khaleej" 2011. S. 4). 